\title{
Elaboration and characterization of snack bars made with ingredients from the Amazon
}

\author{
Isadora Cordeiro dos PRAZERES ${ }^{1}$, Alessandra Ferraiolo Nogueira DOMINGUES ${ }^{2 *}$, \\ Ana Paula Rocha CAMPOS ${ }^{1}$, Ana Vânia CARVALHO² \\ 1 Universidade Federal do Pará, Rua Augusto Corrêa, 01, Bairro Guamá, CEP: 66.075-110, Belém, Pará, Brasil. \\ ${ }^{2}$ Embrapa Amazônia Oriental, Laboratório de Agroindústria, Travessa Doutor Enéas Pinheiro, s/n, Bairro Marco, CEP: 66.095-903, Belém, Pará, Brasil. \\ * Corresponding author: alessandra.domingues@embrapa.br
}

\section{ABSTRACT}

Snack bars were launched on the market as an alternative for people seeking healthier food options. They are popular portable snacks commonly eaten between meals. This study aimed to develop snack bars made with tapioca flour, Brazil nut and native fruit pulps (açaí, cupuaçu, muruci and taperebá) as well as to assess their physical, physicochemical, microbiological and sensory attributes. The preferred concentration of fruit pulp was $10 \%$ in the açaí bar, and $15 \%$ in the cupuaçu, muruci and taperebá bars. The acceptance rate of the açaí bars was greater than $70 \%$ for the attributes appearance, color, texture, and overall impression, but was lower for flavour. This result may be related to the eating habits of some panelists, who eat açaí pulp without adding any other ingredients that can impart the unique flavour of the fruit. The cupuaçu and muruci snack bars had higher sensory acceptance than the açaí and taperebá bars; therefore, they are more likely to have better market prospects.

KEYWORDS: Amazon fruits, Brazil nut, palm oil, sensory analysis, tapioca flour

\section{Elaboração e caracterização de barras de cereais à base de ingredientes da Amazônia}

\section{RESUMO}

Como uma alternativa para as pessoas que procuram opçóes para uma alimentaçáo saudável, as barras de cereais foram lançadas no mercado. Elas são populares como alimentos portáteis e podem ser consumidas entre as refeiçôes. Este trabalho teve como objetivo desenvolver e determinar as variáveis físicas, físico-químicas, microbiológicas e sensoriais de barras de cereais à base de farinha de tapioca, castanha-do-brasil e polpas de frutas regionais (açaí, cupuaçu, muruci e taperebá). A concentração preferida de polpa na barra sabor açaí foi de $10 \%$ e nas barras sabor cupuaçu, muruci e taperebá de $15 \%$. O índice de aceitação da barra sabor açaí foi superior a $70 \%$ nos atributos aparência, cor, textura e impressão global e inferior no sabor. Este comportamento pode estar relacionado à cultura de alguns provadores, os quais têm o hábito de consumir a polpa de açaí sem adição de qualquer outro ingrediente que possa mascarar o sabor intrínseco e peculiar do fruto. As barras sabor cupuaçu e muruci, por apresentarem maior aceitaçấo sensorial, quando comparadas às barras sabor açaí e taperebá, têm melhores perspectivas de mercado caso sejam comercializadas.

PALAVRAS-CHAVE: Frutas regionais, castanha-do-brasil, óleo de palma, análise sensorial, farinha de tapioca 


\section{INTRODUCTION}

Snack bars were introduced in Brazil a decade ago, initially targeted at sports fans, but their target market expanded over time, reaching a much wider public, from students to corporate executives. They are popular portable snacks commonly eaten between meals (Freitas and Moretti 2006; Pallavi et al. 2013).

The use of regional raw materials to formulate snack bars can be very interesting from a nutritional and sensory point of view, besides adding value to raw materials and products from the Amazon region. Tapioca flour, a by-product of cassava (Manihot esculenta Crantz), is widely consumed in the Amazon region and commonly sold on street markets (Alves and Modesto Júnior 2012; Chisté et al. 2012; Silva et al. 2013). Cassava and its by-products are naturally gluten-free foods and therefore can be added to products labeled "glutenfree" (Milde et al. 2010; Schamne et al. 2010).

Brazil nuts (Bertholletia excelsa Humb. \& Bonpl.) are widely recognized for being high in calories and for their nutritional value (Jayasinghe and Caruso 2011). They have been the focus of numerous studies aiming to extract their main nutritional and functional components (John and Shahidi 2010; Stockler-Pinto et al. 2010; Colpo et al. 2014).

The Amazon has the most important repository of fruit species in Brazil (Gordon et al. 2011). Fruits such as cupuaçu (Theobroma grandiflorum (Willd. ex Spreng.) K. Schum.), açaí (Euterpe oleracea Mart.), taperebá (Spondias mobin L.), and muruci (Byrsonima crassifolia (L.) Rich.) are commonly found in this region (Freitas and Mattietto 2013). The açaí pulp has gained increasing international attention due to its nutritional benefits and therapeutic potential (Barros et al. 2015; Romualdo et al. 2015; Barbosa et al. 2016). It contains approximately $13 \%$ protein, $48 \%$ lipids, $1.5 \%$ of total sugars, and several other components such as lignans, fibers, vitamin E and polyphenols (Darnet et al. 2011; Bonomo et al. 2014; Wycoff et al. 2015). The taperebá pulp has, on average, $0.2 \%$ protein, $0.1 \%$ lipids, and $12.4 \%$ carbohydrates (Salgado et al. 2013). Cupuaçu pulp has, on average, $1 \%$ of proteins and lipids and $11 \%$ carbohydrates (Brasil 2015). Muruci pulp contains approximately $0.18 \%$ protein, $0.87 \%$ lipids, and $2.59 \%$ total sugars (Souza et al. 2012). Due to its high content of polyphenols and flavonoids, which confer its high antioxidant capacity, muruci is considered a functional food (Barreto et al. 2009; Almeida et al. 2011; Maldini et al. 2011).

Given the economic and social importance of the cassava production chain in the Northern region of Brazil, and the nutritional and functional characteristics of Brazil nut and Amazonian fruits, the objective of this study was to prepare snack bars using a multicomponent mixture of tapioca flour, Brazil nut, and regional fruit pulps, and to evaluate their physical, physicochemical, microbiological, and sensory variables.

\section{MATERIALS AND METHODS}

The tapioca flour (type 1-granular subclass) and Brazil nut used to prepare the snack bars were purchased from local producers in the vicinity of Belém (state of Pará, northern Brazil). The other ingredients were obtained from commercial establishments.

In addition to the tapioca flour and Brazil nut, oat flakes (Quaker, Porto Alegre, Brazil) and quinoa grains (Mãe Terra, Osasco, Brazil) were also used. The following ingredients were used to prepare the agglutination syrup: refined sugar (União, Sertãozinho, Brazil) glucose syrup (Arcolor, São Paulo, Brazil), maltodextrin (Athletica Nutrition, Matão, Brazil), double distilled glycerin (Arcolor, São Paulo, Brazil), soy lecithin (GastronomyLab, Brasília, Brazil), palm oil (Agropalma, Belém, Brazil), and pulps of açaí (Iaçá, Castanhal, Brazil), cupuaçu, taperebá, and muruci (Camta, Tomé-Açu, Brazil), depending on the particular flavour of the snack bar.

\section{Formulation and elaboration of snack bars}

Preliminary tests were performed changing the ingredients' concentration, searching for the best multicomponent snack bar formulation (Mourão et al. 2012; Khouryieh and Aramouni 2013; Mendes et al. 2013). The chosen formulation was determined considering the best technological interaction between the ingredients. The amount of the dry ingredients and agglutination syrup used in these tests ranged from $60-70 \%$ and $30-40 \%$, respectively. The oat flakes, tapioca flour, and quinoa grains were previously dried in a forced convection/air circulation oven at $100{ }^{\circ} \mathrm{C}$ for 15 minutes.

The agglutination syrup was heated under and stirring in a stainless steel pan, and the total soluble solids content was measured using a digital ABBE refractometer (REFAB-1000S, BioBrix, São Paulo, Brazil) until reaching 85-89 ${ }^{\circ}$ Brix. The dry ingredients were then added to the syrup $\left(95^{\circ} \mathrm{C}\right)$, and the mixture was compressed into a baking pan and allowed to stand at room temperature. After the cooling interval, the mixture was cut into bars of $0.065 \mathrm{~m} \times 0.03 \mathrm{~m} \times 0.015 \mathrm{~m}$ parallelepiped pieces and removed from the pan. The bars, each weighing about $0.025 \mathrm{~kg}$, were individually wrapped in plastic wrap.

\section{Sensory analysis}

Sensory evaluation included the quantitative affective test for preference ordering and acceptance test. The study was approved by the Research Ethics Committee of Universidade da Amazônia (UNAMA) on December 16 ${ }^{\text {th }}, 2014$ (protocol number 1.237.666). 
A sensory test for preference ordering, considering the taste attribute, was used to determine which fruit pulp concentration $(10,15$, or $20 \%)$ in the snack bars was preferred by the tasters. The test was performed with 80 untrained panelists from both sexes. The results obtained were analyzed using a Newell and MacFarlane table (Newell and MacFarlane 1987). After analyzing the results, the fruit pulp concentration preferred by the panelists (final formulation) for each flavour of the snack bars prepared was selected.

The final formulations, prepared after applying the affective test for preference ordering, were evaluated for acceptance using an unstructured 9-point hedonic scale (ranging from like extremely to dislike extremely) considering the attributes appearance, color, flavour, texture, and overall impression. One hundred and two untrained panelists from both sexes and aged between 18 and 63 years participated in these analyses.

The acceptance rate was calculated according to the method proposed by Teixeira et al. (1987) in which the highest score (9) corresponds to $100 \%$ of acceptance. These authors argue that for a product to be considered acceptable based on its sensory characteristics, it is necessary that its acceptance rate is greater than or equal to $70 \%$.

\section{Physical and physicochemical characterization}

The physical and physicochemical variables of the final formulations, prepared after applying the affective test for preference ordering, were also evaluated. The color of the snack bars was determined using a spectrophotometer (Color Quest XE, Hunter Lab, Reston, USA). The color was determined using the CIELAB system ( $\mathrm{L}^{*}, \mathrm{a}^{*}$, and $\mathrm{b}^{*}$ ) (Commission Internationale de L'Eclairage 1986), at $22{ }^{\circ} \mathrm{C}$ and 1-inch viewing distance using a $0.02 \mathrm{~m}$ path length glass cuvette. The results were the mean of 10 replicates.

Texture was determined using a texture analyzer (TA. XT Plus, Stable Micro Systems, Surrey, England). Shear force resistance was measured (expressed in Newton $(\mathrm{N})$ ) using a Warner Bratzler Blade Set (Heavy Duty Platform/ Blade Set with Knife) and the settings for cookies: pre-test speed of $0.0015 \mathrm{~m} \mathrm{~s}^{-1}$, test speed of $0.0020 \mathrm{~m} \mathrm{~s}^{-1}$, post-test speed of $0.010 \mathrm{~m} \mathrm{~s}^{-1}$, and crosshead travel distance of 0,017 $\mathrm{m}$; samples with a dimension of $0.04 \mathrm{~m} \times 0.03 \mathrm{~m} \times 0.015 \mathrm{~m}$ were evaluated. The results were the mean of 10 replicates.

As for the physicochemical characterization, moisture, proteins, lipids, and ashes were determined according to the official method of the Association of Official Analytical Chemists (2011). Fibers were analyzed using the acid detergent method of Goering and Van Soest (1970). The carbohydrate content was calculated by difference based on the values of protein, lipids, ash, and moisture. Energy value was calculated using the Atwater conversion factors: $4000 \mathrm{kcal}$ $\mathrm{kg}^{-1}$ for protein, $4000 \mathrm{kcal} \mathrm{kg}^{-1}$ for carbohydrate, and 9000 $\mathrm{kcal} \mathrm{kg}^{-1}$ for lipids (United States Department of Agriculture 1963). All analyses were performed in triplicate.

\section{Microbiological analysis}

Microbiological analyses were performed according to the APHA (American Public Health Association) official methods (Vanderzant and Splittstoesser 1992), and the Brazilian technical regulation on sanitary microbiological standards for food (Brazil 2001), that defines the most probable number (MPN) analyses for total coliforms, fecal coliforms, yeast, and mold counting, and the determination of presence or absence of Salmonella spp. and Bacillus cereus.

\section{Statistical analysis}

All statistical analyses were performed using the Biostat version 5.0 Software package (Ayres et al. 2007). The data were subjected to analysis of variance (ANOVA) followed by the Tukey test $(\mathrm{p}<0.05)$.

\section{RESULTS}

The final chosen formulation of the açaí, cupuaçu, taperebá, and muruci snack bars prepared with different fruit pulp concentrations was defined after the preliminary tests with different concentrations of the ingredients (Table 1). The açaí and cupuaçu bars containing 10\% and 15\% of pulp were preferred by the panelists, therefore these concentrations were chosen as the pulp percentage to be used in the final formulation of these bars. As there was no significant difference between the muruci and taperebá snack bars prepared with different pulp concentrations $(10,15$, and $20 \%$ ), the pulp concentration used in the final formulation of these bars was $15 \%$.

Table 1. Formulation of snack bars prepared with different Amazonian fruit (açaí, cupuaçu, muruci, taperebá) pulp concentrations.

\begin{tabular}{lccc}
\hline Ingredients & \multicolumn{3}{c}{ Concentration (\%) } \\
\hline Fruit pulps & 10.0 & 15.0 & 20.0 \\
Refined sugar & 14.0 & 11.0 & 10.0 \\
Maltodextrin & 7.0 & 7.0 & 6.0 \\
Glycerin & 3.5 & 2.5 & 2.0 \\
\hline Palm oil & 1.5 & 1.5 & 1.5 \\
Glucose syrup & 12.0 & 12.0 & 12.0 \\
Soy lecithin & 2.0 & 1.0 & 1.5 \\
Tapioca flour & 20.0 & 20.0 & 19.0 \\
Oat flakes & 14.0 & 14.0 & 13.0 \\
Quinoa grains & 6.0 & 6.0 & 5.0 \\
Brazil nut & 10.0 & 10.0 & 10.0 \\
\hline
\end{tabular}


The results of the affective test for preference ordering for the açaí, cupuaçu, muruci, and taperebá snack bars are presented in Table 2. According to the Newell and MacFarlane table, the critical value of absolute differences in the rank sums (ordering test) was $30(\mathrm{p}<0.05)$. This means that, if the difference in the rank sums is greater than or equal to the tabulated value, there is a significant difference between same flavour formulations, at the chosen significance level.

For açaí snack bars there was a significant difference between the pulp concentrations of 10 and $15 \%$ and 10 and $20 \%$, but no significant difference between the bars containing 15 and $20 \%$ of pulp. For the cupuaçu snack bars, significant differences were observed between the pulp concentrations of 10 and $15 \%$ and 15 and 20\%. For muruci and taperebá snack bars no difference was observed among the pulp concentrations tested.

In the color analysis of the snack bars (Table 3) the higher the $\mathrm{L}^{*}$ value, the lighter (less dark) the specimen. The cupuaçu, muruci, and taperebá bars were the lightest, with the highest $\mathrm{L}^{*}$ values, and the açaí bars were the darkest. All samples had positive chromaticity values ( $\mathrm{a}^{*}$ and $\mathrm{b}^{*}$ ), and thus were in the red and yellow regions. There was no significant difference between the snack bars in terms of texture (Table 4).

The physicochemical analysis of the snack bars (Table 5) showed that the moisture content varied between 7.38 and $9.17 \%$. No significant difference was observed in the ash and protein contents among the snack bars. Lipid, carbohydrate, and fiber contents were very similar, although there were significant differences between some formulations.

The mold and yeast analyses of açaí, cupuaçu, muruci and taperebá bars were $1.0 \times 10^{2}, 1.5 \times 10,2.0 \times 10$ and $1.3 \times 10$ $\mathrm{CFU}$, respectively. For coliforms at $35^{\circ} \mathrm{C}$, the results were $23 \mathrm{NMP} / \mathrm{g}$ (açaí and cupuaçu bars) and <3NMP/g (muruci and taperebá bars). For coliforms at $45^{\circ} \mathrm{C}$ and Bacillus cereus, the results were $<3 \mathrm{NMP} / \mathrm{g}$ and $<10^{-1} \mathrm{CFU}$, respectively, for all bars analyzed. Salmonella spp. was not detected in any of the samples analyzed.

The scores obtained for the sensory attributes in the acceptance test indicated that the snack bars were generally well accepted by the panelists for all sensory attributes evaluated (Figure 1). The scores given by the panelists ranged between 6 and 8 . The hedonic scale point value 6 corresponds to "like slightly" and the hedonic value 8 to "like extremely".

With regard to appearance and color, there were no significant differences between the four formulations. As for the attributes flavour, texture, and overall impression, there were significant differences between some formulations. Açaí and taperebá had significantly low scores for flavour. Taperebá had the lowest scores in all attributes, particularly so for flavour, texture and overall impression. The cupuaçu and muruci snack bars were the only ones with acceptance rate greater than $70 \%$ for all sensory attributes evaluated.
Table 2. Sensory test for preference ordering for snack bars prepared with different Amazonian fruit pulp concentrations.

\begin{tabular}{lccc}
\hline \multirow{3}{*}{ Snack bar } & \multicolumn{3}{c}{ Fruit pulp (\%) } \\
\cline { 2 - 4 } & 10 & 15 & 20 \\
\hline Açaí & $182 \mathrm{a}$ & $151 \mathrm{~b}$ & $147 \mathrm{~b}$ \\
Cupuaçu & $154 \mathrm{~b}$ & $184 \mathrm{a}$ & $142 \mathrm{~b}$ \\
Muruci & $149 \mathrm{a}$ & $163 \mathrm{a}$ & $168 \mathrm{a}$ \\
Taperebá & $154 \mathrm{a}$ & $162 \mathrm{a}$ & $165 \mathrm{a}$ \\
\hline
\end{tabular}

Values are the sum of the ranks assigned by all panelists to each sample. Values followed by the same letter in the line are not significantly different from one another according to the Newell and MacFarlane table (Newell and MacFarlane 1987).
Table 4. Instrumental texture measurements for the snack bars prepared with different Amazonian fruit pulps.

\begin{tabular}{lc}
\hline Snack bar & Shear force resistance $(\mathrm{N})$ \\
\hline Açaí & $97.68 \pm 7.44 \mathrm{a}$ \\
Cupuaçu & $93.50 \pm 18.99 \mathrm{a}$ \\
Muruci & $108.85 \pm 19.47 \mathrm{a}$ \\
Taperebá & $97.98 \pm 21.99 \mathrm{a}$ \\
\hline
\end{tabular}

Values are the mean followed by the standard deviation. Means followed by the same letter in the column are not significantly different from one another by the Tukey test $(p<0.05)$.

Table 3. Color variables of snack bars prepared with different Amazonian fruit pulps.

\begin{tabular}{lcccccc}
\hline Snack bar & $L^{*}$ & CV & $\mathrm{a}^{*}$ & CV & b* & CV \\
\hline Açaí & $46.71 \pm 2.97 \mathrm{c}$ & 6.35 & $8.01 \pm 0.80 \mathrm{a}$ & 9.99 & $9.66 \pm 0.53 \mathrm{c}$ & 5.49 \\
Cupuaçu & $75.01 \pm 1.95 \mathrm{a}$ & 2.60 & $2.90 \pm 0.33 \mathrm{c}$ & 9.57 & $16.87 \pm 1.70 \mathrm{~b}$ & 10.08 \\
Muruci & $69.79 \pm 1.71 \mathrm{~b}$ & 2.45 & $4.85 \pm 0.82 \mathrm{~b}$ & 16.91 & $23.65 \pm 2.40 \mathrm{a}$ & 10.15 \\
Taperebá & $70.22 \pm 1.72 \mathrm{~b}$ & 2.45 & $5.37 \pm 0.79 \mathrm{~b}$ & 14.71 & $24.09 \pm 2.28 \mathrm{a}$ & 9.46 \\
\hline
\end{tabular}

CIELAB system. $L^{*}$ defines lightness, $a^{*}$ denotes the red/green value, $b^{*}$ the yellow/blue value (Commission Internationale de L'Eclairage 1986 ) and CV the coefficient of variation Values are means followed by standard deviation. Means followed by the same letter in the column are not significantly different from one another by the Tukey test $(p<0.05)$. 
Table 5. Physicochemical characterization of snack bars prepared with different Amazonian fruit pulps (wet base).

\begin{tabular}{lcccc}
\hline \multirow{2}{*}{ Variables } & \multicolumn{4}{c}{ Snack bar } \\
\cline { 2 - 5 } & Açaí & Cupuaçu & Muruci & Taperebá \\
\hline Moisture (\%) & $7.48 \pm 0.04 \mathrm{~b}$ & $9.17 \pm 0.06 \mathrm{a}$ & $7.38 \pm 0.06 \mathrm{~b}$ & $6.92 \pm 0.19 \mathrm{c}$ \\
Ash (\%) & $0.97 \pm 0.12 \mathrm{a}$ & $0.95 \pm 0.14 \mathrm{a}$ & $0.95 \pm 0.14 \mathrm{a}$ & $0.97 \pm 0.12 \mathrm{a}$ \\
\hline Lipids (\%) & $10.08 \pm 0.72 \mathrm{~b}$ & $10.34 \pm 0.06 \mathrm{ab}$ & $11.22 \pm 0.09 \mathrm{a}$ & $10.87 \pm 0.17 \mathrm{ab}$ \\
Protein (\%) & $4.72 \pm 0.25 \mathrm{a}$ & $5.47 \pm 0.17 \mathrm{a}$ & $5.53 \pm 0.55 \mathrm{a}$ & $5.43 \pm 0.46 \mathrm{a}$ \\
\hline Fiber (\%) & $5.87 \pm 0.03 \mathrm{a}$ & $4.05 \pm 0.21 \mathrm{~b}$ & $4.40 \pm 0.39 \mathrm{~b}$ & $4.51 \pm 0.11 \mathrm{~b}$ \\
Carbohydrate (\%) & $76.75 \pm 0.90 \mathrm{a}$ & $74.05 \pm 0.06 \mathrm{c}$ & $74.90 \pm 0.40 \mathrm{bc}$ & $75.79 \pm 0.67 \mathrm{ab}$ \\
Caloric value (kcal kg-1) & $4166.00 \pm 72.10$ & $4112.50 \pm 10.50$ & $4228.10 \pm 19.70$ & $4227.40 \pm 29.10$ \\
\hline
\end{tabular}

Values are the mean followed by the standard deviation. Means followed by the same letter on the line are not significantly different from one another by the Tukey test $(p<0.05)$.

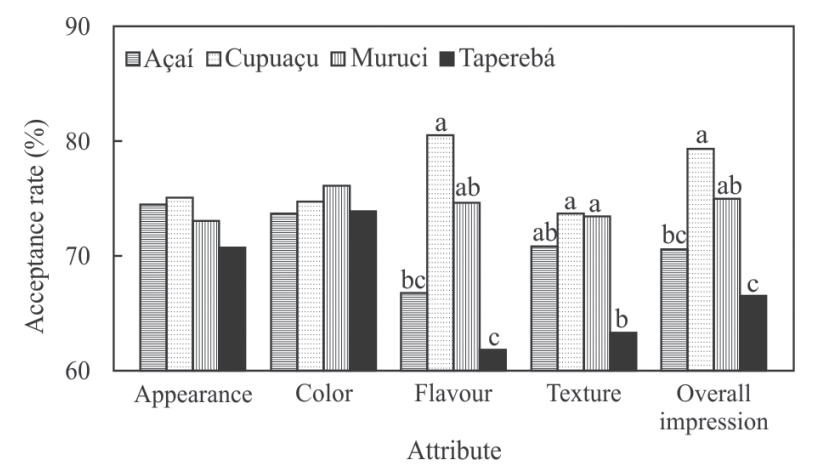

Figure 1. Acceptance rate of snack bars for the sensory attributes appearance, color, flavour, texture, and overall impression. Bars topped by the same letter are not significantly different according to the Tukey test $(p<0.05)$.

\section{DISCUSSION}

The differences in $\mathrm{L}^{*}$ values (lightness) were expected because the color of fruit pulps used in the snack bar formulations are different from one another. The significantly higher variable $\mathrm{a}^{*}$ value for açaí is related to the higher concentration of red pigments in this formulation, while the variable $b^{*}$ values for muruci and taperebá bars showed higher concentration of yellow pigments. Differences in the structure, size, and shape of the ingredients, as well as their interaction, can explain the difference between the forces exerted by the texture analyzer on the samples, which resulted in the high observed standard deviations (Silva et al. 2011).

Determining food moisture is very important since water is one of the factors favoring the growth and proliferation of fungi, yeasts, and bacteria. The moisture values were in compliance with the Collegiate Directory Resolution No. 263 of September $22^{\text {th }} 2005$, which establishes the limit of $15 \%$ moisture content for cereal-based food products (Brasil 2005). The difference between the ash, protein, lipid, carbohydrate, and fiber contents among the snack bars can be attributed to the different chemical composition of the fruit pulps, and, in the case of the açaí bar, it can be due to the low percentage of this ingredient in the formulation. The caloric values measured can be explained by the concentration of ingredients rich in carbohydrates and lipids. According to the Collegiate Directory Resolution No. 359 of December $23^{\text {th }} 2003$, snack bars should not exceed $150 \mathrm{kcal}$ per serving (Brasil 2003). Therefore, each snack bar prepared (1 unit) in this study weighs approximately $0.025 \mathrm{~kg}$, resulting in approximately $105 \mathrm{kcal}$ per unit.

According to Brazilian legislation, the reference values for coliforms at 35 and $45^{\circ} \mathrm{C}$, and for Bacillus cereus in food are, respectively, $<5 \times 10 \mathrm{NMP} / \mathrm{g}$, and $<5 \times 10^{2} \mathrm{CFU}$, while Salmonella spp. are to be completely absent (Brasil 2001). Therefore our snack bars were within the legal microbiological criteria, and were suitable for consumption. Although existing Brazilian technical regulations on microbiological standards in food do not require control of food spoilage fungus in snack bars, there should be close and regular monitoring to minimize risks to the health of consumers.

The low score observed for flavour of açaí snack bars in the acceptance tests, despite high scores in the other attributes, may be related to the eating habits of some panelists, who eat açaí pulp without adding any other ingredients (sugar, honey, etc.) that may alter the unique flavour of the fruit.

\section{CONCLUSION}

The use of Amazonian regional raw materials enabled the preparation of snack bars different from commercial bars, with high nutritional quality and unique flavour. The use of exotic fruits from the Amazon region in the development of new products adds value to these products and enhances their visibility in the domestic and international markets. The cupuaçu and muruci snack bars had consistently high scores 
in sensory acceptance attributes, indicating good commercial potential. Açaí and taperebá bars scored below sensory acceptability in one or more attributes with the formulations tested in here.

\section{ACKNOWLEDGEMENTS}

The authors are grateful to the Conselho Nacional de Desenvolvimento Científico e Tecnológico (CNPq - Brasil) for financial support (process number 407764/2013-5).

\section{REFERENCES}

Almeida, M.M.B.; Sousa, P.H.M.; Arriaga, A.M.C.; Prado, G.M.; Magalhães, C.E.C.; Maia, G.A.; Lemos, T.L.G. 2011. Bioactive compounds and antioxidante activity of fresh exotic fruits from northeastern Brazil. Food Research International, 44: 2155-2159.

Alves, R.; Modesto Júnior, M.S. 2012. Custo e rentabilidade do processamento de farinha de tapioca no distrito de Americano, município de Santa Isabel, Pará. Amazônia: Ciência \& Desenvolvimento, 15: 91-102.

Association of Official Analytical Chemists. 2011. Official methods of analysis of the Association of Official Analytical Chemists. AOAC International, Gaithersburg, 2590p.

Ayres, M.; Ayres Júnior, M.; Ayres, D.L.; Santos, A. 2007. Bioestat - Aplicaçôes estatísticas nas áreas das ciências biomédicas. UFPA, Belém, 324p.

Barbosa, P.O.; Pala, D.; Silva, C.T.; Souza, M.O.; Amaral, J.F.; Vieira, R.A.L.; Folly, G.A.F.; Volp, A.C.P.; Freitas, R.N. 2016. Açai (Euterpe oleracea Mart.) pulp dietary intake improves cellular antioxidant enzymes and biomarkers of serum in healthy women. Nutrition, 32: 674-680.

Barreto, G.P.M.; Benassi, M.T.; Mercadante, A.Z. 2009. Bioactive compounds from several tropical fruits and correlation by multivariate analysis to free radical scavenger activity. Journal of the Brazilian Chemical Society, 20: 1856-1861.

Barros, L.; Calhelha, R.C.; Queiroz, M.J.R.P.; Santos-Buelga, C.; Santos, E.A.; Regis, W.C.B.; Ferreira, I.C.F.R. 2015. The powerful in vitro bioactivity of Euterpe oleracea Mart. seeds and related phenolic compounds. Industrial Crops and Products, 76: 318-322.

Bonomo, L.F.; Silva, D.N.; Boasquivis, P.F.; Paiva, F.A.; Guerra, J.F.; Martins, T.A.; et al. 2014. Açaí (Euterpe oleracea Mart.) modulates oxidative stress resistance in Caenorhabditis elegans by direct and indirect mechanisms. PLoS ONE, 9: e89933.

Brasil, 2001. Resolução-RDC no 12, 02 de janeiro de 2001. Regulamento técnico sobre padróes microbiológicos para alimentos. (www.anvisa.gov.br). Accessed on 17/08/2015.

Brasil, 2003. Resolução-RDC no 359, 23 de dezembro de 2003. Regulamento técnico de porçóes de alimentos embalados para fins de rotulagem nutricional (www.anvisa.gov.br). Accessed on $17 / 08 / 2015$.

Brasil, 2005. Resolução-RDC no 263, 22 de setembro de 2005. Regulamento técnico para produtos de cereais, amidos, farinhas e farelos (www.anvisa.gov.br). Accessed on 17/08/2015.
Brasil. 2015. Alimentos regionais brasileiros. 2da ed. Ministério da Saúde, Brasília. 484p.

Chisté, R.C.; Silva, P.A.; Lopes, A.S.; Pena, R.S. 2012. Sorption isotherms of tapioca flour. International Journal of Food Science and Technology, 47: 870-874.

Commission Internationale de L'Eclairage. 1986. Colorimetry. Second Edition. 3ra ed. Commission Internationale de L'Eclairage, Vienna, 72p.

Colpo, E.; Vilanova, C.D.D.A.; Reetz, L.G.B.; Duarte, M.M.M.F.; Farias, I.L.G.; Meinerz, D.F. et al. 2014. Brazilian nut consumption by healthy volunteers improves inflammatory parameters. Nutrition, 30: 459-465.

Darnet, S.; Serra, J.L.; Rodrigues, A.M.C.; Silva, L.H.M. 2011. A high-performance liquid chromatography method to measure tocopherols in assai pulp (Euterpe oleracea). Food Research International, 44: 2107-2111.

Freitas, G.C.; Mattietto, R.A. 2013. Ideal sweetness of mixed juices from Amazon fruit. Ciência e Tecnologia de Alimentos, 33: 148-154.

Freitas, G.C.; Moretti, R.H. 2006. Caracterização e avaliação sensorial de barra de cereais funcional de alto teor proteico e vitamínico. Ciência e Tecnologia de Alimentos, 26: 318- 324.

Goering, H.K.; Van Soest, P.J. 1970. Forage fiber analysis (apparatus, reagents, procedures and some applications). Agricultural Research Service, Washington, 379p.

Gordon, A.; Jungfer, E.; Silva, B.A.; Maia, J.G.S.; Marx, F. 2011. Phenolic constituents and antioxidante capacity of four underutilized fruits from the Amazon region. Journal of Agricultural and Food Chemistry, 59: 7688-7699.

Jayasinghe, S.B.; Caruso, J.A. 2011. Investigation of Se-containing proteins in Bertholletia excelsa H.B.K. (Brazil nuts) by ICPMS, MALDI-MS and LC-ESI-MS methods. International Journal of Mass Spectrometry, 307: 16-25.

John, J.A.; Shahidi, F. 2010. Phenolic compounds and antioxidant activity of Brazil nut (Bertholletia excelsa). Journal of Functional Foods, 2: 196-209.

Khouryieh, H.; Aramouni, F. 2013. Effect of flaxseed flour incorporation on the physical properties and consumer acceptability of cereal bars. Food Science and Technology International, 19: 549-556.

Maldini, M.; Montoro, P.; Pizza, C. 2011. Phenolic compounds from Byrsonima crassifolia L. bark: Phytochemical investigation and quantitative analysis by LC-ESI MS/MS. Journal of Pharmaceutical and Biomedical Analysis, 56: 1-6.

Mendes, N.S.R.; Gomes-Ruffi, C.R.; Lage, M.E.; Becker, F.S.; Melo, A.A.M.; Silva, F.A.; Damiani, C. 2013. Oxidative stability of cereal bars made with fruit peels and baru nuts packaged in different types of packaging. Food Science Technology, 33: 730-736.

Milde, L.B.; Ramallo, L.A.; Puppo, M.C. 2010. Gluten-free bread based on tapioca starch: texture and sensory studies. Food Bioprocess Technology, 5: 888-896.

Mourão, L.H.E.; Pontes, D.F.; Rodrigues, M.C.P.; Brazil, I.M.; Cavalcante, M.T.B. 2012. Avaliação de barras de cereais de caju ameixa. Alimentos e Nutrição, 23: 287-295. 
Newell, G.J.; MacFarlane, J.D. 1987. Expanded tables for multiple comparison procedures in the analysis of ranked data. Journal of Food Science, 52: 1721-1725.

Pallavi, B.V.; Chetana, R.; Ravi, R.; Reddy, R.Y. 2013. Moisture sorption curves of fruit and nut cereal bar prepared with sugar and sugar substitutes. Journal of Food Science and Technology, 50: $1-7$.

Romualdo, G.R.; Fragoso, M.F.; Borguini, R.G.; Santiago, M.C.P.A.; Fernandes, A.A.H.; Barbisan, L.F. 2015. Protective effects of spray-dried açaí (Euterpe oleracea Mart) fruit pulp against initiation step of colon carcinogenesis. Food Research International, 77: 432-440.

Salgado, H.; Lourenço, L.; Sousa, C.; Araújo, E. 2013. Dessert made from cupuassu fruit on eastern amazon: preparation and shelf life. Journal of Food Processing and Preservation, 37: 391-398.

Schamne, C.; Dutcosky, S.D.; Demiate, I.M. 2010. Obtention and characterization of gluten-free baked products. Ciência $e$ Tecnologia de Alimentos, 30: 741-750.

Silva, F.D.; Pante, C.F.; Prudêncio, S.H.; Ribeiro, A.B. 2011. Elaboração de uma barra de cereal de quinoa e suas propriedades sensoriais e nutricionais. Alimentos e Nutrição, 22: 63-69.

Silva, P.A.; Cunha, R.L.; Lopes, A.S; Pena, R.S. 2013. Caracterização de farinhas de tapioca produzidas no estado do Pará. Ciência Rural, 43: 185-191.
Souza, V.R.; Pereira, P.A.P.; Queiroz, F.; Borges, S.V.; Carneiro, J.D.S. 2012. Determination of bioactive compounds, antioxidant activity and chemical composition of Cerrado Brazilian fruits. Food Chemistry, 134: 381-386.

Stockler-Pinto, M.B.; Mafra, D.; Farage, N.E.; Boaventura, G.T.; Cozzolino, S.M. 2010. Effect of Brazil nut supplementation on the blood levels of selenium and glutathione peroxidase in hemodialysis patients. Nutrition, 26: 1065-1069.

Teixeira, E.; Meinert, E.M.; Barbetta, P.A. 1987. Análise sensorial de alimentos. Editora da UFSC, Florianópolis, 180p.

United States Department of Agriculture. 1963. Composition of foods. Agricultural Research Center Service, Washington, 190p.

Vanderzant, T.; Splittstoesser, E.F. 1992. Compendium of methods for the microbiological examination offoods. American Public Health Association, Washington, 1219p.

Wycoff, W.; Luo, R.; Schauss, A.G.; Neal-Kababick, J.; Sabaa-Srur, A.U.O.; Maia, J.G.S.; Tran, K.; Richards, K.M.; Smith, R.E. 2015. Chemical and nutritional analysis of seeds from purple and white (Euterpe oleracea Mart.). Journal of Food Composition and Analysis, 41: 181-187.

Received: 01/08/16

Accepted: 06/03/17 
